\title{
Research on the Non-compete Obligation of Directors in China's Company Law
}

\author{
Su Wang \\ College of Information \& Business, Zhongyuan University of Technology, Zhengzhou, Henan Province, 45000
}

\begin{abstract}
Non-compete is an important obligation of directors, and also is an important manifestation of directors' loyalty obligations. Directors are generally involved in the company's management, so they are familiar with company's trade secrets, major business decisions, investment and other insider information. If the law allow the directors doing business in the range of company's trading profit for themselves or a third party, the directors may use company secrets or business relationship for their own personal gain, and then damage the interests of the company and shareholders. China's current Company Law has set forth non-compete obligation of directors, but some provisions are abstract. This paper attempts to analyze our directors' non-compete obligations in order to point out legislative defects, and put forward suggestions for improvement.

Index Terms - Director; Non-compete; Legislative defects; Suggestions for improvement
\end{abstract}

\section{Introduction}

Director is the company's actual managers, and also is executer of company's specific economic exchanges. Therefore, all the provisions of national law in the exercise of the duties of directors must fulfill certain obligations. The company is only a kind of investment tool of shareholder, and the company hopes to use this kind of investment tool to obtain return. Accordingly, the director's obligation of the company is the obligation to shareholders, but to shareholders, that is a whole obligation, rather than an obligation to a specific shareholder or a certain type of shareholders.

\section{Overview of Director's Non-compete}

\section{A. Concept of Director's Non-compete}

Non-compete, also known as "non-competition", means that someone shall not be promised to engage in competitive business. Non-compete means that directors and managers cannot engage in the same business activities for themselves or others, because they serve the same business or engage in activities will damage interests of the company.

\section{B. Legal Characteristics of Non-compete}

1) Non-compete is a Negative Obligation

Civil obligation is a party in civil legal relation who limits behavior in order to meet the other party's interest. From the concept of non-compete, obligor burdens non-compete obligation to obligee according to law or the prior agreement.

2) Director's Non-compete Obligation Limits Unfair Competition Behavior

Director's competition trade violates the principle of honesty and credit. But competition trade is different from acts of unfair competition. First, the former bans legal business behavior in a given situation and the latter prohibits illegal business practices. Secondly, the former regulates rights and obligations between specific subjects, and the latter aims to regulate the rights and obligations between general market players.

3) Non-compete Obligation of Directors Has a Certain Time and Area Restrictions

A certain period of time limits the tenure of directors within a certain period after leaving. The area should be limited to the company's business areas, and companies have started to develop or ready to develop a regional scope.

\section{Non-compete Obligation Director System Problems in China}

\section{A. Uncertain Period}

China's current law does not specify the starting and ending times of non-compete obligation. China's Labor Contract Law article 24 about the time limit on non-compete provision is "The term counted from the termination or ending of the employment contract, for which a person as mentioned in the preceding paragraph is subject to competition restrictions in terms of his working for a competing Employer that produces the same type of products or is engaged in the same type of business as his current employer, or in terms of his establishing his own business to produce the same type of products or engage in the same type of business, shall not exceed two years." In view of the fact that between the directors and the company is generally not a labor contract, it is uncertain that provisions of competition can be applied to the board of directors of the company after leaving. The time limit is the essential terms of the director's non-compete. If the time limit is short, it is not conducive to the protection of commercial secrets and other information units. If the time limit is long, it will infringe the lawful interests of directors. At the same time, the effectiveness of non-compete and the scheduled period is not stipulated.

\section{B. Lack of Geographical Restrictions}

Geographical restriction is the geographical scope of director's non-compete. Germany, Japan and the British case provides geographical restrictions of director's noncompete. There is no such provision in China. China Company Law Article 70 provides "Absent approval by the state authorized investment entity or state authorized department, the chairman, vice-chairman, a director, or the general manager may not serve concurrently as the person in charge of any other limited liability company, joint stock limited 
company or any other business organization". Article 148, paragraph 5 "Without the consent of the shareholders" meeting or the shareholders' assembly, seeking business opportunities for himself or any other person by taking advantages of his authorities, or operating for himself or for any other person any like business of the company he works for". This provision seems to mean the geographical scope is the whole country. Even if we speculate that refers to the whole country, this is not reasonable. The business scope of some smaller companies is limited to just one province. The director operates the same business in the other province after leaving, but the behavior cannot form a business competition to the original company. It should be permitted, and it can be conducive to economic development.

\section{Fuzzy Range of Non-compete}

First, the existing law on self-management or for others is not clearly defined. Self-management refers to business in someone's own name, or whether it also includes the other style which is attributable to their own business without own name? Business for others is defined in the name or vested interests? Secondly, the current law does not clearly define what similar business is. Similar business license or identification is enshrined in the articles of association prevail, or in the actual operation of the subject? The author believes that similar services can be understood to include competitive and non-competitive services business, which in addition to the geographical coverage of the company's business operations and the company has no intention to develop the region's business and the company can not be considered competing business.

\section{Legal Liability is not Comprehensive}

Liability of directors should bear in violation of noncompete obligations, in which civil legal consequences only referred to the disgorgement and the right to compensation. China's relevant laws and regulations do not compete against directors who are implementing acts prohibited giving a clear industry regulations, including without limitation the right as a request, scheduled period. None of the methods to stop the infringement gives specific provisions. Many foreign countries have more specific regulations, that the company enjoys the injunction. Director has the obligation to stop the infringement. China's Company Law has not yet specified exercise prescription disgorgement, which gives the company the right to exercise the fall left a larger space, but cannot produce the negative effects go.

\section{Non-compete Obligation of Directors Recommends Improving the System}

\section{A. Clear Deadline Range}

Director of the non-compete period, the law should give a specific range. Law of the non-compete obligation of directors after the resignation should not require compliance, but for independent directors, reference may be applicable to the Labor Contract Law Article 24, paragraph 2 "The term, counted from the termination or ending of the employment contract, for which a person as mentioned in the preceding paragraph is subject to competition restrictions in terms of his working for a competing Employer that produces the same type of products or is engaged in the same type of business as his current Employer, or in terms of his establishing his own business to produce the same type of products or engage in the same type of business, shall not exceed two years." This provision applies to non-independent directors is also very reasonable. It is recommended to join such a requirement for all directors of the Company Law. While leaving the situation of directors and the company signed a contract, also refer to the Labor Contract Law Article 24, paragraph 1 "The personnel subject to competition restrictions shall be limited to the Employer's senior management, senior technicians and other personnel with a confidentiality obligation. The scope, territory and term of the competition restrictions shall be agreed upon by the Employer and the Employee, and such agreement shall not violate laws and regulations."

\section{B. Perfect Geographical Restrictions}

Geographical restrictions means workers non-compete provisions of directors shall not carry out the geographical scope of gaming industry. The size of the British think of Prohibition general and former regional business units affected area as well as market share and other factors. Employers any regional or general expansion of the non-competition provisions shall not engage in the same industry. It would constitute a violation of the autonomy of workers careers. Most believe that the geographical scope of the company and the directors should be operating in the region may generate substantial competition between a restricted area of Prohibition. I believe that this alone is not comprehensive enough. To improve the geographical restrictions on the provisions of the directors must consider the statutory time limit of prohibition.

\section{Improve Field Limit}

The field of non-competition is limited to the same kind of business in Clause 149 of "Company Law" of China. I think the legal concept "same business" should be clarified with a more detailed and more clearly definition. The field of noncompetition of the directors should be correspond to the field where the staff may know or may acquire of the business secret or other important information when occupying the position, and particularly, it shall not extend to the general knowledge, experience, skills, or other industries which are irrelevant with the business secret.

\section{Improve the Legal Responsibility \\ 1) Improve the Claiming Right of Stopping the Infringement}

I believe that, as long as the directors violate any noncompetition obligation, the company will be entitled to request stopping the competing behavior, even if the directors have no fault. According to the general principles of Civil Law, the obligee is entitled to ask stopping the breaching behavior if the obligor breaches or executes the harmful behavior to the obligee. Providing stop the infringement is one of the way to 
bear civil liability Stipulated in Article 134 of general rules of Civil Law, a director assuming responsibility shall bear the liability stopping the infringement, correspondingly, as rights holders the company should enjoy the right to ask stopping infringement. If the shareholder firstly find the violation of non-competition obligation of directors, the shareholder shall be entitled to ask the company to execute the claiming right of stopping the infringement. At the same time, a director's fault will not be the premise of such claiming right, but the objective committed prohibitive non-competition behavior should be the basis of the liability. It should be suggested that the following clauses may be added into the Company Law: the company is entitled to require the directors stopping the infringement behavior if the directors is breaching or will commit the non-competition obligation. If the company is indolent, the shareholders have the right to ask the company to execute the claiming right. That is as long as the director is still in progress or about to execute a statutory prohibitive noncompete behavior, the claiming right should be existing there.

2) Improve Disgorgement Right

The benefit acquired by the directors of committing the non-competition obligation shall be owned by the company, namely the company shall have the ownership to the benefit, which can also be called the disgorgement right. There are corresponding stipulations in Clause 149 in Company Law of China. However, the premise is that the director has acquired the benefits. If no benefit got, the disgorgement will not be implemented. However, the disgorgement is one of formation right, pursuant to its effect. One party's declaration of will can change the existing legal relations. Every country established the prescription and scheduled period for the disgorgement right. It set forth in the laws of Japan and Taiwan that the existing term of the disgorgement shall be no more than one year occurring from the trade date or the benefit acquiring date. It should be scheduled term here. In Germany, the term shall be 3 months from the date on which the board of directors or the board of supervisors know or should know the occurrence of the obligation, or 5 years from the benefit acquiring date. It is reasonable to put a long term for disgorgement, on account of the implement of the disgorgement shall be after the resolution of the company's organizations, so it shall not be too short. It should be suggested to add the prescription of disgorgement to Company Law of China, that is to say, the existing term is one year from the date on which company know or should know it, shorter than the prescription restriction of 2 years. However, the disgorgement will be terminated after 5 years from the date on which the directors commit the infringement behavior.

\section{3) Claiming Right for the Recovery of Damages}

The company should be entitled to require the directors to compensate the actual losses under the conditions of any breach of the non-competition obligations and incurred damages to the company. There are no similar stipulations in Company Law of China, so it needs to be added into the law. It will be better to protect the company's benefit if both the intervening right and the claiming right of recovery of damages be vested by the Company Law. It attributed to the two factors. First, in the company's viewpoint, it will be better to make up for the damages under the conditions of the damages incurred more than the benefit acquired by the directors who breached the non-competition obligations. Second, in the director's viewpoint which breached noncompetition obligation, it is in favor of forming the psychological compulsion to the directors so as to reduce the occurrence of the behavior of breaching non-competition, if the liability is not limited to return the benefit acquired already but will also bear much more liabilities.

\section{References}

[1] Zhao Xu-dong. System Design of New Company Law. Law Press, 2006.

[2] Chao Shun-ming. Research on the liability for damage to directors of the Limited Corporation. Chinese Legal Publishing Press, 2005.

[3] Yu Duo. Research on the Obligation of Directors' noncompete. Journal of Gansu Institute of Adult Education Law, 2006.

[4] Sun Yu. Explore the Disgorgement System of Company in Our Country. Economist, 2009 (12).

[5] Gui Ju-ping. Research on Several Legal Issues of Prohibition of Business Strife. Study on the Law, 2001 (1).

[6] Guo Sheng-xuan. On the recognition of business strife in the judicial practice. Hebei Law, 2009 (1).

[7] Ma Jia-qi. Perfecting the Legal System and the Outgoing Director Obligations. Legal Forum, 2007 (2). 